\section{BRAZIULIAN JOURNAL}

OF MEDICAL AND BIOLOGICAL RESH ARCH

www.bjournal.com.br
ISSN 0100-879X

Volume 43 (04) 325-408 April 2010

BIOMEDICAL SCIENCES

AND

CLINICAL INVESTIGATION

Braz J Med Biol Res, March 2010, Volume 43(4) 350-355

Effect of gallium-arsenide laser, gallium-aluminum-arsenide laser and healing ointment on cutaneous wound healing in Wistar rats

R.V. Gonçalves, J.M.S. Mezêncio, G.P. Benevides, S.L.P. Matta, C.A. Neves, M.M. Sarandy and E.F. Vilela

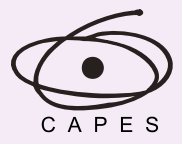

Ministério da Educação

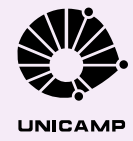




\title{
Effect of gallium-arsenide laser, gallium-aluminum- arsenide laser and healing ointment on cutaneous wound healing in Wistar rats
}

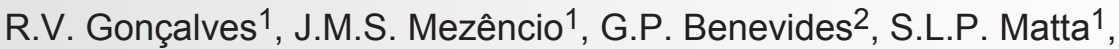 \\ C.A. Neves ${ }^{1}$, M.M. Sarandy ${ }^{3}$ and E.F. Vilela ${ }^{4}$ \\ ${ }^{1}$ Departamento de Biologia Geral, Universidade Federal de Viçosa, Viçosa, MG, Brasil \\ 2Departamento de Ciências Biológicas, Universidade Federal de Ouro Preto, Ouro Preto, MG, Brasil \\ ${ }^{3}$ Departamento de Biologia Geral, Universidade Presidente Antônio Carlos, Governador Valadares, MG, Brasil \\ ${ }^{4}$ Departamento de Fitotecnia, Universidade Federal de Viçosa, Viçosa, MG, Brasil
}

\begin{abstract}
This study determined the effects of gallium-aluminum-arsenide laser (GaAIAs), gallium-arsenide laser (GaAs) and Dersani ${ }^{\circledR}$ healing ointment on skin wounds in Wistar rats. The parameters analyzed were: type I and III collagen fiber concentrations as well as the rate of wound closure. Five wounds, $12 \mathrm{~mm}$ in diameter, were made on the animals' backs. The depth of the surgical incision was controlled by removing the epithelial tissue until the dorsal muscular fascia was exposed. The animals were anesthetized with ketamine and xylazine via intraperitoneal injection. The rats were randomly divided into five groups of 6 animals each, according to the treatment received. Group 1 (L4): GaAs laser (4 J/cm²); group 2 (L30): GaAIAs laser (30 J/ $\mathrm{cm}^{2}$ ); group 3 (L60): GaAlAs laser $\left(60 \mathrm{~J} / \mathrm{cm}^{2}\right.$ ); group 4 (D): Dersani ${ }^{\circledR}$ ointment; group 5 (control): $0.9 \%$ saline. The applications were made daily over a period of 20 days. Tissue fragments were stained with picrosirius to distinguish type I collagen from type III collagen. The collagen fibers were photo-documented and analyzed using the Quantum software based on the primary color spectrum (red, yellow and blue). Significant results for wound closing rate were obtained for group 1 (L4), $7.37 \mathrm{~mm} / \mathrm{day}$. The highest concentration of type III collagen fibers was observed in group 2 (L30; $37.80 \pm 7.10 \%)$, which differed from control $(29.86 \pm 5.15 \%)$ on the 20th day of treatment. The type I collagen fibers of group 1 (L4; $2.67 \pm 2.23 \%)$ and group 2 (L30; 2.87 $\pm 2.40 \%)$ differed significantly from control $(1.77 \pm 2.97 \%)$ on the 20th day of the experiment.
\end{abstract}

Key words: Cicatrization; Laser; Healing ointment; Collagen I and III; Cutaneous wound

\section{Introduction}

Skin wounds are present in approximately $10 \%$ of hospitalized patients and $20 \%$ of bedridden patients treated at home, with consequent high financial costs and ranking second as the most common cause of work absenteeism (1). The healing of skin wounds is a highly organized dynamic process that works to restore the structure and function of the damaged tissue. In this process, a complex interaction occurs between cells, extracellular matrix, blood vessels, proteases, cytokines, and chemokines (2). The healing process involves inflammatory cell migration, granulation tissue synthesis, collagen and proteoglycan deposition, and scar maturation, being associated with intense remodeling (3).

The main component of a mature scar is type I collagen, and in the healing wounds, fibroblasts are recruited and induced to synthesize collagen in a process called fibroplasia, initiated by the granulation tissue in the wound, and rich in type III collagen (4). This tissue is made up of loose collagen matrix, fibronectin and hyaluronic acid, also containing macrophages, fibroblasts, and new vessels. As the tissue recovery process advances, the granulation tissue is replaced by a less vascularized and more resistant tissue rich in type I collagen (5).

Most therapeutic interventions are designed to facilitate the wound healing process, with emphasis on the importance of protecting wounds to prevent complications (6). Essential fatty acids such as those derived from linoleic acid are among the resources supporting the healing process (7). Dersani ${ }^{\circledR}$ ointment belongs to this group, being used

Correspondence: R.V. Gonçalves, Departamento de Biologia Geral, Universidade Federal de Viçosa, Edifício Shotaro Shymoia, Avenida PH Rolfs, s/n, 35570-000 Viçosa, MG, Brasil. E-mail: reggysvilela@yahoo.com.br

Received May 3, 2009. Accepted March 1, 2010. Available online March 19, 2010. Published April 12, 2010. 
in any type of cutaneous lesion as a bactericide during the different phases of the process (3).

The laser technique is one of the methods used to hasten the recovery of tissue functionality in the treatment of wounded tissues. Due to the efficacy of laser procedures in the healing process, they are recommended for the recovery of the tissue by inducing vessel dilatation, collagen synthesis and by increasing tissue oxygenation (8). According to Enwemeka et al. (9), all phases of the healing process are positively affected by laser treatment, with wavelength and energy density being crucial factors for successful treatment (10).

The results of a study conducted by Reddy (11) indicated that one of the devices used, gallium-arsenide (GaAs) laser, was effective in healing wounds of diabetic rats by promoting a significant increase in the amount of collagen. This device is extensively used in procedures aimed at treating skin wounds and also the reason it was selected for the present study. Gallium-aluminum-arsenide (GaAIAs) laser (904 nm), when applied to the microcirculation of live rats, promotes dilatation of the irradiated arterioles, followed by an increase in arteriolar blood flow. A good tissue vascularization and an efficient collagen deposition are determining factors for successful cicatrization (6).

Since the identification of adequate healing-promoting techniques is highly beneficial for patient care and immediate cost reduction, investigating the healing effect of different laser modalities and determining their action on collagen fibers throughout the healing process are of fundamental importance to establish mechanisms to promote faster, safer and infection-free cicatrization, reducing the healing and recovery time, and improving the quality of life of the patients at a lower cost.

The aim of the present study was to determine the effect of GaAs laser $\left(4 \mathrm{~J} / \mathrm{cm}^{2}\right)$, GaAIAs laser (30 and $60 \mathrm{~J} / \mathrm{cm}^{2}$ ) and Dersani ${ }^{\circledR}$ healing ointment on the skin healing process by determining the amount of type I and type III collagen fibers, and the rate of wound closure.

\section{Material and Methods}

Ten-week-old male Wistar rats (Rattus norvegicus) weighing on average $324 \mathrm{~g}$, from the Central Animal House of the Health and Biological Sciences Center, Federal University of Viçosa (UFV), were used. The animals were maintained under natural light and humidity conditions (temperature $22^{\circ} \mathrm{C}$; $12-\mathrm{h}$ light/dark cycles) in individual cages cleaned daily, fed once a day and offered water ad libitum. The experiment was conducted according to the Guiding Principles in the Use of Animals Ethics Committee of the Faculty of Physiotherapy of Minas Gerais (FAMINAS; registration \#005/2008), taking the proper care of the animals into consideration.

The animals were anesthetized with ketamine and $x y$ lazine via intraperitoneal injection ( $60 \mathrm{mg} / \mathrm{kg}$ body weight).
Trichotomy was then performed on the dorsolateral region of all animals and five circular secondary intention wounds of $12 \mathrm{~mm}$ in diameter were made in the dorsolateral region of the animals by performing a surgical incision in the skin and subcutaneous cell tissue using a scalpel. The area of the wounds was previously marked using crystal violet and checked using an analogical pachymeter (Mitutoyo Sul Americana Ltda ${ }^{\circledR}$, Brazil). The depth of the surgical incision was controlled by removing the epithelial tissue until the dorsal muscular fascia was exposed. All therapies were initiated $6 \mathrm{~h}$ after surgery and repeated daily for the 20 days of the experiment. Fragments of the different wounds containing edges and center were collected every 4 days to compare with the unwounded tissue. The size of the fifth wound was measured every 4 days with the use of a caliper, and this wound was used as control to verify how fast the wounds closed.

The rats were divided randomly into five groups of 6 animals each. Their wounds were cleaned with $0.9 \%$ saline once a day in the morning. In group 1 (L4), the animals were submitted to $\mathrm{GaAs}$ laser radiation at a wavelength of $904 \mathrm{~nm}$ and energy density of $4 \mathrm{~J} / \mathrm{cm}^{2}\left(0.8 \mathrm{~J} / \mathrm{mm}^{2}\right.$ per point). Group 2 (L30) was treated with GaAlAs laser at a wavelength of $830 \mathrm{~nm}$ and energy density of $30 \mathrm{~J} / \mathrm{cm}^{2}(6 \mathrm{~J} /$ $\mathrm{mm}^{2}$ per point). In group 3 (L60), the animals were treated with $\mathrm{GaAlAs}$ laser at a wavelength of $830 \mathrm{~nm}$ and energy density of $60 \mathrm{~J} / \mathrm{cm}^{2}$ (12 J/mm $\mathrm{mm}^{2}$ per point). The scanning technique was used and the duration of radiation application was automatically adjusted. The Quasar laser device (Dentoflex ${ }^{\circledR}$, Brazil) was used. Group 4 (D) was treated with Dersani ${ }^{\circledR}$ ointment (caprylic acid, capric acid, lauric acid, soy lecithin, vitamin A, vitamin E, caproic acid, and sunflower oil - linoleic acid), with $0.1 \mathrm{~g}$ of the ointment being applied once a day. Group 5 (control group) consisted of animals whose wounds were only cleaned with $0.9 \%$ saline once a day.

The animals were weighed every 4 days, an interval coinciding with the removal of the wound fragments. The fragments removed for histological analysis were preserved in $10 \%$ buffered formaldehyde for $24 \mathrm{~h}$. The material was processed for paraffin embedding by ethanol dehydration, diaphanization with xylene, infiltration and embedding in paraffin wax. Cuts of $4 \mu \mathrm{m}$ were obtained with a rotary microtome (Reichert-Jung 2045 Multicut ${ }^{\circledR}$, Germany) and stained with picrosirius.

Images of histological sections were captured with a polarization microscope (Olympus $A X-70^{\circledR}$, Brazil) and the amount of type I and III collagen fibers was evaluated. Four random images of different parts of the field were obtained from each sample. The images were analyzed using the Quantum software program (Department of Soil Science, Federal University of Viçosa, Viçosa, MG, Brazil) that differentiates fibers by the colors red, green and blue in each image. The intervals defining the identification of the colors red, green and black were previously standardized and 
then used for all images obtained. Red represented type I collagen fibers, green type III collagen fibers and black the regions where no fiber was found. The program provides the percentage of the area corresponding to each color.

\section{Statistical analysis}

The data were analyzed statistically by the KruskalWallis test, with the level of significance set at $5 \%$.

\section{Results}

The most significant results regarding the extent of wound reduction were obtained for group 1 (L4; Table 1), which also presented the fastest rate of wound closure (7.37 mm/day; Table 2).

Analysis of the percentage of type III collagen fibers showed that, on the fourth day of the experiment, groups 2 (L30) and 3 (L60) presented the highest percentage of fibers $(P<0.05)$. On the 8th day of treatment, no statistical differences were found among the groups. On the 12th day, all groups presented a statistically significant difference compared with the control group $(P<0.05)$ except group 3. Moreover, group 4 (D) presented a lower percentage of collagen fibers than group 2 (L30) $(\mathrm{P}<0.05)$. On the 20th day, group 2 (L30) presented a significantly higher percentage of type III collagen fibers than the other groups $(\mathrm{P}<$ $0.05)$, whereas group 1 (L4), treated with $4 \mathrm{~J} / \mathrm{cm}^{2}$ laser, had a significantly lower percentage of type III collagen fibers than the other groups $(P<0.05)$. These data are shown in Table 3.

Table 1. Extent of wound diameter reduction after 20 days of different treatments.

\begin{tabular}{lc}
\hline Treatment & Reduction of extent of wound (\%) \\
\hline Group 1 $\left(4 \mathrm{~J} / \mathrm{cm}^{2}, 904 \mathrm{~nm}\right)$ & $94.76 \pm 0.16^{*}$ \\
Group 2 $\left(30 \mathrm{~J} / \mathrm{cm}^{2}, 830 \mathrm{~nm}\right)$ & $77.6 \pm 0.45$ \\
Group 3 $\left(60 \mathrm{~J} / \mathrm{cm}^{2}, 830 \mathrm{~nm}\right)$ & $83.43 \pm 0.21$ \\
Group 4 $($ Dersani & $81 \pm 0.14$ \\
Group 5 $(0.9 \%$ saline $)$ & $81 \pm 0.21$ \\
\hline
\end{tabular}

Data are reported as means \pm SD for 6 rats in each group. Group 1 = gallium-arsenide laser (GaAs); group 2 = gallium-aluminumarsenide laser (GaAlAs); group 3 = GaAlAs laser; group 4 = Dersani ${ }^{\circledR}$ ointment; group $5=$ control cleaned with saline daily. ${ }^{*} \mathrm{P}<$ 0.05 , group 1 compared to all other groups (Kruskal-Wallis test).

Table 2. Partial rate and average rate of extent of wound closure in relation to time and treatments.

\begin{tabular}{|c|c|c|c|c|c|c|}
\hline \multirow[t]{2}{*}{ Treatment } & \multicolumn{5}{|c|}{ Rate of wound closure $(\mathrm{mm})$} & \multirow[t]{2}{*}{ Average rate (mm/day) } \\
\hline & 4 days & 8 days & 12 days & 16 days & 20 days & \\
\hline Group 1* (4 J/cm², $904 \mathrm{~nm})$ & $7.9 \pm 6.8$ & $13.8 \pm 1.5$ & $5.2 \pm 1.2$ & $6.8 \pm 5.8$ & $2.96 \pm 1.6$ & $7.37 \pm 2.6$ \\
\hline Group $2\left(30 \mathrm{~J} / \mathrm{cm}^{2}, 830 \mathrm{~nm}\right)$ & $9.75 \pm 3.6$ & $17.84 \pm 4.5$ & $12.08 \pm 1.9$ & $8.83 \pm 2.1$ & $6.08 \pm 1.1$ & $7.01 \pm 1.1$ \\
\hline Group $3\left(60 \mathrm{~J} / \mathrm{cm}^{2}, 830 \mathrm{~nm}\right)$ & $6.75 \pm 2.4$ & $12.70 \pm 1.8$ & $5.66 \pm 3.1$ & $5.33 \pm 0.36$ & $4.54 \pm 2.64$ & $7.00 \pm 1.4$ \\
\hline Group 4 (Dersani $\left.{ }^{\circledR}\right)$ & $1.96 \pm 0.36$ & $16.58 \pm 6.07$ & $12.70 \pm 2.4$ & $3.08 \pm 1.04$ & $4.87 \pm 0.9$ & $7.05 \pm 1.6$ \\
\hline Group 5 ( $0.9 \%$ saline $)$ & $7.1 \pm 6.8$ & $8.2 \pm 1.5$ & $9.6 \pm 3.1$ & $4.8 \pm 4.0$ & $4.41 \pm 1.3$ & $6.80 \pm 2.6$ \\
\hline
\end{tabular}

Data are reported as means \pm SD for 6 rats in each group. Group 1 = gallium-arsenide laser (GaAs); group 2 = gallium-aluminumarsenide laser (GaAlAs); group $3=$ GaAlAs laser; group $4=$ Dersani ${ }^{\circledR}$ ointment; group $5=$ control cleaned with saline daily. ${ }^{*} P<0.05$, group 1 compared to all other groups (Kruskal-Wallis test).

Table 3. Average values of type III collagen fiber count related to time and treatment with saline, Dersani ${ }^{\circledR}$ ointment and different laser types and intensities.

\begin{tabular}{lcccccc}
\hline & \multicolumn{5}{c}{ Concentration of collagen fiber III (\%) } \\
\cline { 2 - 7 } Group & 0 days & 4 days & 8 days & 12 days & 16 days & 20 days \\
\hline Group 1 $\left(4 \mathrm{~J} / \mathrm{cm}^{2}, 904 \mathrm{~nm}\right)$ & $12.43 \pm 4.70$ & $3.12 \pm 1.86$ & $17.92 \pm 12.57$ & $27.50 \pm 11.89$ & $19.89 \pm 13.28$ & $16.22 \pm 5.44$ \\
Group 2 $\left(30 \mathrm{~J} / \mathrm{cm}^{2}, 830 \mathrm{~nm}\right)$ & $16.18 \pm 0.58$ & $4.21 \pm 2.20$ & $18.36 \pm 16.03$ & $33.32 \pm 17.05$ & $25.24 \pm 8.33$ & $37.80 \pm 7.10^{*}$ \\
Group 3 $\left(60 \mathrm{~J} / \mathrm{cm}^{2}, 830 \mathrm{~nm}\right)$ & $10.40 \pm 4.95$ & $3.30 \pm 1.92$ & $18.84 \pm 13.85$ & $10.40 \pm 4.95$ & $12.35 \pm 6.79$ & $32.12 \pm 11.17$ \\
Group 4 (Dersani $\left.{ }^{\circledR}\right)$ & $15.54 \pm 8.28$ & $2.55 \pm 1.29$ & $15.93 \pm 11.82$ & $21.60 \pm 14.53$ & $18.48 \pm 8.53$ & $25.90 \pm 4.56$ \\
Group 5 (saline) & $10.19 \pm 5.62$ & $3.01 \pm 2.69$ & $13.015 \pm 12.69$ & $12.96 \pm 12.84$ & $30.73 \pm 7.01$ & $29.86 \pm 5.15$ \\
\hline
\end{tabular}

Data are reported as means \pm SD for 6 rats in each group. Group 1 = gallium-arsenide laser (GaAs); group $2=$ gallium-aluminumarsenide laser (GaAIAs); group $3=$ GaAlAs laser; group $4=$ Dersani ${ }^{\circledR}$ ointment; group $5=$ control cleaned with saline daily. ${ }^{*} \mathrm{P}<0.05$, group 2 compared to all other groups on the 20th day of treatment (Kruskal-Wallis test). 
Analysis of type I collagen fibers (Table 4) showed that on the fourth day of the experiment, group 2 (L30) had a significantly higher percentage $(P<0.05)$ compared with the other groups, except group 4 (D). Also, a significant

Table 4. Average values of type I collagen fiber count related to time and treatment with saline, Dersani ${ }^{\circledR}$ ointment and different laser types and intensities.

\begin{tabular}{llccccc}
\hline Treatment & \multicolumn{5}{c}{ Concentration of collagen fiber I (\%) } \\
\cline { 2 - 7 } & \multicolumn{1}{c}{ 0 days } & 4 days & 8 days & 12 days & 16 days & 20 days \\
\hline Group 1 $\left(4 \mathrm{~J} / \mathrm{cm}^{2}, 904 \mathrm{~nm}\right)$ & $22.38 \pm 15.72$ & $0.69 \pm 0.58$ & $0.23 \pm 0.73$ & $3.57 \pm 12.74$ & $1.05 \pm 0.46$ & $2.67 \pm 2.23$ \\
Group 2* $\left(30 \mathrm{~J} / \mathrm{cm}^{2}, 830 \mathrm{~nm}\right)$ & $18.24 \pm 6.58$ & $2.83 \pm 1.02$ & $0.19 \pm 0.40$ & $2.91 \pm 3.32$ & $1.26 \pm 2.23$ & $2.87 \pm 2.40$ \\
Group 3 $\left(60 \mathrm{~J} / \mathrm{cm}^{2}, 830 \mathrm{~nm}\right)$ & $22.76 \pm 12.93$ & $1.16 \pm 0.77$ & $0.36 \pm 1.04$ & $2.50 \pm 2.90$ & $3.17 \pm 3.77$ & $2.50 \pm 2.81$ \\
Group 4 (Dersani $\left.{ }^{\circledR}\right)$ & $18.75 \pm 12.26$ & $2.08 \pm 1.97$ & $0.29 \pm 1.27$ & $2.51 \pm 1.83$ & $2.61 \pm 4.61$ & $0.60 \pm 1.61$ \\
Group 5 $(0.9 \%$ saline $)$ & $21.75 \pm 10.06$ & $1.59 \pm 0.86$ & $0.51 \pm 0.48$ & $3.02 \pm 1.65$ & $0.14 \pm 0.35$ & $1.77 \pm 2.97$ \\
\hline
\end{tabular}

Data are reported as means \pm SD for 6 rats in each group. Group 1 = gallium-arsenide laser (GaAs); group 2 = gallium-aluminum-arsenide laser (GaAlAs); group 3 = GaAlAs laser; group 4 = Dersani ${ }^{\circledR}$ ointment; group 5 = control cleaned with saline daily. ${ }^{*} \mathrm{P}<0.05$, group 2 compared to all other groups, except group 4 (Kruskal-Wallis).

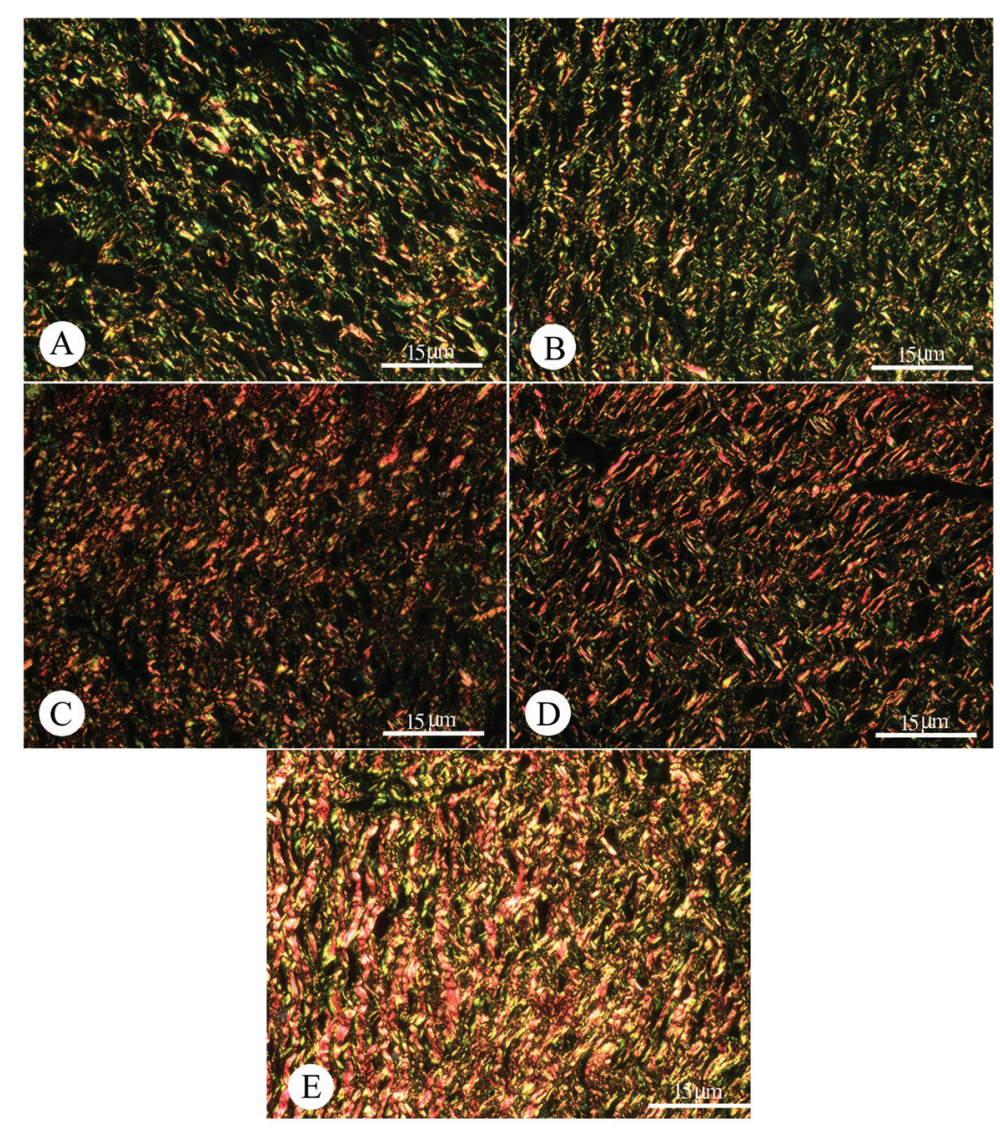

Figure 1. Histological sections of Wistar rat skin on the 20th day of the experiment stained with picrosirius and observed under a polarization microscope. $A$, Group $5=$ control cleaned with $0.9 \%$ saline daily; $B$, group 4 treated with Dersani ${ }^{\circledR}$ ointment; $C$, group 1 treated with gallium-arsenide laser $\left(\mathrm{GaAs}, 4 \mathrm{~J} / \mathrm{cm}^{2}\right) ; D$, group 3 treated with gallium-aluminum-arsenide laser $\left(\mathrm{GaAl} A \mathrm{~s}, 60 \mathrm{~J} / \mathrm{cm}^{2}\right) ; E$, group 2 treated with GaAIAs laser, $30 \mathrm{~J} / \mathrm{cm}^{2}$. Groups 2 (L30) and 1 (L4) had a significant increase in collagen fibers compared with group $4(D)$ and the control group ( $<<0.05)$. Group $3(L 60)$ showed a significantly higher proportion of type I collagen fibers than group 4 (D; $P<0.05)$. 
proportional increase in type I collagen fibers was observed in group 4 (D) compared with group 1 (L4) ( $<$ < 0.05). On the 8 th and 12 th days of treatment, no significant difference was found among the different groups. On the 16th day, group 1 (L4) and group 3 (L60) had a significant increase compared with the control group $(P<0.05)$. On the 20th day, groups 2 (L30) and 1 (L4) had a significant increase compared with group $4(D)$ and the control group $(P<0.05)$. Group 3 (L60) showed a significantly higher proportion of type I collagen fibers than group 4 (D) $(P<0.05)$. Figure 1 shows the presence of type I and type III collagen fibers and their distribution on the 20th day of the experiment.

\section{Discussion}

In the present study, different wavelengths as well as different energy densities were used to determine the efficiency of the collagen synthesis treatments in promoting a faster and higher quality cicatrization. In vitro studies on fibroblast laser irradiation have reported a proliferative effect on protein synthesis depending on the characteristics and parameters of the type of laser used, such as wavelength, form of emission and energy density $(12,13)$.

The present study shows that, based on the rate of wound closure, the best results were obtained for group 1 (L4) on the 8th day of the experiment. The closing of the wounds treated with $\mathrm{GaAs}$ laser, at a wavelength of $904 \mathrm{~nm}$ and energy density of $4 \mathrm{~J} / \mathrm{cm}^{2}$, was also faster compared with the other groups. According to Medrado et al. (14) and Pugliese et al. (15), the use of GaAlAs laser at lower energy densities had a significant effect on the cicatrization of tissues, accelerating tissue repair through decreased edema, improved granulation tissue and fibroblast proliferation stimulation. In contrast to our results, they showed that $4 \mathrm{~J} / \mathrm{cm}^{2}$ laser is less effective for early wound closure during every experiment (15). According to Enwemeka et al. (9) and Woodruff et al. (16), the use of 632.8 and 780 $\mathrm{nm}$ laser therapy positively influences several tissue repair parameters, including reduced wound area and healing time, while the best energy density results range between 19 and $24 \mathrm{~J} / \mathrm{cm}^{2}$ and densities below $8.25 \mathrm{~J} / \mathrm{cm}^{2}$ and above $130 \mathrm{~J} /$ $\mathrm{cm}^{2}$ do not produce good wound closure results.

Considering the constitution of the wound related to type III collagen fibers, group 2 (L30; $\lambda=830 \mathrm{~nm}$ and 30 $\mathrm{J} / \mathrm{cm}^{2}$ ) was the most effective in producing these fibers. It is interesting to note that low densities would be important for early wound closure, but not to promote type III collagen synthesis. Similar results were obtained by Mendez et al. (17), who investigated the use of $830-\mathrm{nm}$ GaAlAs laser at

\section{References}

1. Blanes L, Duarte IS, Calil JA, Ferreira LM. [Clinical and epidemiologic evaluation of pressure ulcers in patients at the Hospital São Paulo]. Rev Assoc Med Bras 2004; 50: energy densities of 20 and $50 \mathrm{~J} / \mathrm{cm}^{2}$ for tissue repair in cutaneous wounds of rats. The most effective results were obtained for the group treated at a density of $50 \mathrm{~J} / \mathrm{cm}^{2}$.

Regarding type I collagen fibers, groups $2(\mathrm{~L} 30 ; \lambda=830$ $\left.\mathrm{nm}, 30 \mathrm{~J} / \mathrm{cm}^{2}\right)$ and $1\left(\mathrm{~L} 4 ; \lambda=830 \mathrm{~nm}, 4 \mathrm{~J} / \mathrm{cm}^{2}\right)$ presented a significant increase compared to control and to group 4 (D). This important point indicates that scars reached maturity early in the groups treated with these two types of laser and seems to indicate the efficiency of laser radiation in the replacement of type III collagen fibers with type I collagen fibers. One reason could be that in the $4 \mathrm{~J} / \mathrm{cm}^{2}$ laser-treated group, although a lower type III collagen fiber count was observed, replacement was faster and more efficient, providing this group with a significantly higher amount of type I fibers at the end of the experiment compared to the other groups. According to Reddy (11), type I collagen fibers are thicker, supplying the scar with greater traction strength and resistance.

The proliferation of collagen fibers promoted by laser radiation was also observed by Fung et al. (18) when analyzing the therapeutic effect of GaAlAs $63.2 \mathrm{~J} / \mathrm{cm}^{2}$ laser on the repair structure of the medial collateral ligament of rats. These investigators found that the animals receiving laser radiation presented wider fibers than those in the control group, and that the distribution of those fibers was similar in the groups receiving irradiation for 3 to 6 weeks. In the groups irradiated with $63.2 \mathrm{~J} / \mathrm{cm}^{2} \mathrm{GaAlAs}$ laser, a larger number of collagen fibers was also found per area of transverse section. According to $\mathrm{Ng}$ et al. (19), multiple laser applications to the lesion may improve collagen morphology and healing.

In the present study, at the end of the experiment, the group treated with GaAlAs $60 \mathrm{~J} / \mathrm{cm}^{2}$ laser did not differ significantly from the control group, but only differed from the Dersani ${ }^{\circledR}$ group (group 4), demonstrating that high energy densities do not present good results for type I collagen fibers. After analyzing different wavelengths and energy doses applied to fibroblast cells, it was found that the highest number of mitoses was reached with a dose of $15 \mathrm{~J} / \mathrm{cm}^{2}$ and that above $60 \mathrm{~J} / \mathrm{cm}^{2}$ there was a reduction in cell division $(20,21)$. According to Meirelles et al. (2), marked maturation of granulation tissue is found on the 21 st day of treatment using the energy density of $20 \mathrm{~J} / \mathrm{cm}^{2}$ at 660 and $780 \mathrm{~nm}$.

We conclude that an energy density of $30 \mathrm{~J} / \mathrm{cm}^{2}$ was the most efficient in stimulating the production of type I and type III collagens, while the use of $4 \mathrm{~J} / \mathrm{cm}^{2}$ was more effective in the synthesis of type I collagen, and mainly in speeding up the rate of wound closing.

182-187.

2. Meirelles GC, Santos JN, Chagas PO, Moura AP, Pinheiro AL. A comparative study of the effects of laser photobiomod- 
ulation on the healing of third-degree burns: a histological study in rats. Photomed Laser Surg 2008; 26: 159-166.

3. Maldebaum SH, Santis EP, Maldebaum MHS. Cicatrização: conceitos atuais e recursos auxiliares - Parte II. An Bras Dermatol 2003; 78: 393-410.

4. Lahmann NA, Halfens RJ, Dassen T. Prevalence of pressure ulcers in Germany. J Clin Nurs 2005; 14: 165-172.

5. Singer AJ, Clark RA. Cutaneous wound healing. $N$ Engl $J$ Med 1999; 341: 738-746.

6. Posten W, Wrone DA, Dover JS, Arndt KA, Silapunt S, Alam M. Low-level laser therapy for wound healing: mechanism and efficacy. Dermatol Surg 2005; 31: 334-340.

7. Magalhaes MS, Fechine FV, Macedo RN, Monteiro DL, OIiveira CC, Brito GA, et al. Effect of a combination of medium chain triglycerides, linoleic acid, soy lecithin and vitamins A and $\mathrm{E}$ on wound healing in rats. Acta Cir Bras 2008; 23: 262-269.

8. Ihsan FR. Low-level laser therapy accelerates collateral circulation and enhances microcirculation. Photomed Laser Surg 2005; 23: 289-294.

9. Enwemeka CS, Parker JC, Dowdy DS, Harkness EE, Sanford LE, Woodruff LD. The efficacy of low-power lasers in tissue repair and pain control: a meta-analysis study. Photomed Laser Surg 2004; 22: 323-329.

10. Zhang F, Lei MP, Oswald TM, Pang Y, Blain B, Cai ZW, et al. The effect of vascular endothelial growth factor on the healing of ischaemic skin wounds. Br J Plast Surg 2003; 56: 334-341.

11. Reddy GK. Photobiological basis and clinical role of lowintensity lasers in biology and medicine. $J$ Clin Laser Med Surg 2004; 22: 141-150.

12. Maiya GA, Kumar P, Rao L. Effect of low intensity heliumneon (He-Ne) laser irradiation on diabetic wound healing dynamics. Photomed Laser Surg 2005; 23: 187-190.

13. Corazza AV, Jorge J, Kurachi C, Bagnato VS. Photobio- modulation on the angiogenesis of skin wounds in rats using different light sources. Photomed Laser Surg 2007; 25: 102-106.

14. Medrado AR, Pugliese LS, Reis SR, Andrade ZA. Influence of low level laser therapy on wound healing and its biological action upon myofibroblasts. Lasers Surg Med 2003; 32: 239-244.

15. Pugliese LS, Medrado AP, Reis SRA, Andrade ZA. The influence of low-level laser therapy on biomodulation of collagen and elastic fibers. Pesqui Odontol Bras 2003; 17: 307-313.

16. Woodruff LD, Bounkeo JM, Brannon WM, Dawes KS, Barham $C D$, Waddell $D L$, et al. The efficacy of laser therapy in wound repair: a meta-analysis of the literature. Photomed Laser Surg 2004; 22: 241-247.

17. Mendez TM, Pinheiro AL, Pacheco MT, Nascimento PM, Ramalho LM. Dose and wavelength of laser light have influence on the repair of cutaneous wounds. J Clin Laser Med Surg 2004; 22: 19-25.

18. Fung DT, Ng GY, Leung MC, Tay DK. Effects of a therapeutic laser on the ultrastructural morphology of repairing medial collateral ligament in a rat model. Lasers Surg Med 2003; 32: 286-293.

19. Ng GY, Fung DT, Leung MC, Guo X. Ultrastructural comparison of medial collateral ligament repair after single or multiple applications of GaAlAs laser in rats. Lasers Surg Med 2004; 35: 317-323.

20. Goncalves WL, Souza FM, Conti CL, Cirqueira JP, Rocha WA, Pires JG, et al. Influence of He-Ne laser therapy on the dynamics of wound healing in mice treated with anti-inflammatory drugs. Braz J Med Biol Res 2007; 40: 877-884.

21. Rochkind S, Ouaknine GE. New trend in neuroscience: lowpower laser effect on peripheral and central nervous system (basic science, preclinical and clinical studies). Neurol Res 1992; 14: 2-11. 